\title{
Retraction: Severe contact dermatitis due to camomile: a common complementary remedy with potential sensitization risks
}

Sibel Dogan

\section{Retraction}

This article [1] has been retracted by the authors. Although the patients originally gave consent to publication of their cases and images, they withdrew this consent shortly after publication. The article is no longer available online in order to protect patient confidentiality. The author apologizes for the inconvenience.

Received: 7 August 2013 Accepted: 7 August 2013

Published: 12 August 2013

\section{Reference}

1. Dogan S: Severe contact dermatitis due to camomile: a common complementary remedy with potential sensitization risks. Allergy Asthma Clin Immunol 2013, 9:26.

Submit your next manuscript to BioMed Central and take full advantage of:

- Convenient online submission

- Thorough peer review

- No space constraints or color figure charges

- Immediate publication on acceptance

- Inclusion in PubMed, CAS, Scopus and Google Scholar

- Research which is freely available for redistribution

Submit your manuscript at www.biomedcentral.com/submit
C Biomed Central 